Articles

\title{
Design of Website-Based Queue Retrieval Application on Andi Motor using Codeigniter Framework
}

\author{
Andreas Gunaryo ${ }^{1}$, Yusuf Kurnia ${ }^{2}$ \\ 1, 2 Universitas Buddhi Dharma, Teknik Informatika, Banten, Indonesia
}

\begin{tabular}{|c|c|}
\hline SUBMISSION TRACK & A B S T R A C $\mathbf{T}$ \\
\hline $\begin{array}{l}\text { Recieved: Jan 6, } 2020 \\
\text { Final Revision: Jan 28, } 2020 \\
\text { Available Online: Feb 26, } 2020\end{array}$ & \multirow{5}{*}{$\begin{array}{l}\text { Conventional queues have become a common polemic in } \\
\text { society. The duration of the process and waiting time for } \\
\text { the queue greatly disrupts daily activities. Queuing is not } \\
\text { fun for many people, especially if the queue is long and } \\
\text { irregular. To deal with irregular queues, an application is } \\
\text { needed that helps to queue more fun and has certainty of } \\
\text { time. In the workshop, the queue retrieval system and } \\
\text { waiting for the queue are usually done on the spot, this will } \\
\text { not be a problem if the queue is not long, but if the queue is } \\
\text { too long it will cause various problems. This journal } \\
\text { discusses the design of website-based queuing applications } \\
\text { using framework codeIgniter, where features are made } \\
\text { based on the wishes of customers, so that this application } \\
\text { has the purpose of facilitating customers in queuing } \\
\text { wherever and whenever and customers will have certainty } \\
\text { of time to queue. The design of this application uses the } \\
\text { MVC method contained in the codeigniter framework to } \\
\text { separate data and display and how to process it. }\end{array}$} \\
\hline KEYWORD & \\
\hline Queue, Website, Codeigniter, MVC & \\
\hline CORRESPONDENCE & \\
\hline E-mail: andreasgunaryo@gmail.com & \\
\hline
\end{tabular}

\section{INTRODUCTION}

One problem in people's lives is the problem in the queue. Often we see many people waiting in a public service facility, for example, when carrying out vehicle repairs in public workshops. Generally, everyone has experienced something like this in his life. Therefore, it can be said that the queue has become a part of everyone's life. At the Andi Motor workshop, service to customer satisfaction is very important, so efforts will be made to improve the quality of service. "To retain customers, a place of business always strives to provide the best service, including providing fast services so that customers do not wait in line for too long" [1]. The queuing system contained in Andi Motor has not been able to meet customer needs in functionality, because it is still done manually and displays queuing information with limited scope. For some customers, queuing using the current queue system is less pleasant, especially if the queue is long and irregular. Dense scenes often make people uncomfortable to wait in line. When they want to queue and wait in line, some people also feel the uncertainty of time about how much longer they will get their turn to be served. They cannot wait while doing 
outside activities even for a short time, because it will result in losing queues.

\section{METHODS}

The method used includes 2 (two) main parts, namely data collection methods and design methods [2].

\section{Data Collection Method a. Literature Review}

This method is done by searching and gathering theories, journals, news and information about the application of taking a website-based queue through books and the internet [3] [4].

\section{b. Observation}

This method is done by observing the problems that occur and the data studied to consider making useful features to be included in the application.

\section{c. Requirement Elicitation}

This method is done by conducting a survey of several respondents to get information about application needs that are used as a reference in the application design.

\section{Design Method}

The design method used is the waterfall method, one of the software development processes that flows from one phase to the next [5] [6]. The development process is divided into 5 main phases, namely:

\section{Requirements Analysis and Definition}

All requirements are analyzed and defined in detail which is then used as a system specification.

2. System and Software Design

Making architectural designs, both for software and hardware, so as to build the whole system. The whole system abstraction is described complete with its relation.

3. Implementation and Unit testing

The design that was available was realized into a program with code development (coding). After becoming a program unit, each unit will be tested to determine whether each unit is in accordance with specifications.

4. Integration and System Testing

Program units that are in accordance with the specifications will be integrated into a unified system. Tests will be carried out again on an intact system.

\section{Operation and Maintenance}

At this stage the program installation is carried out and operated for the benefit of the customer. In the process, maintenance must continue during the operation of the program. Repair is done if errors are found in the program. Improvement can also be done at this stage, so as to produce new system requirements that can improve the services of the program itself.

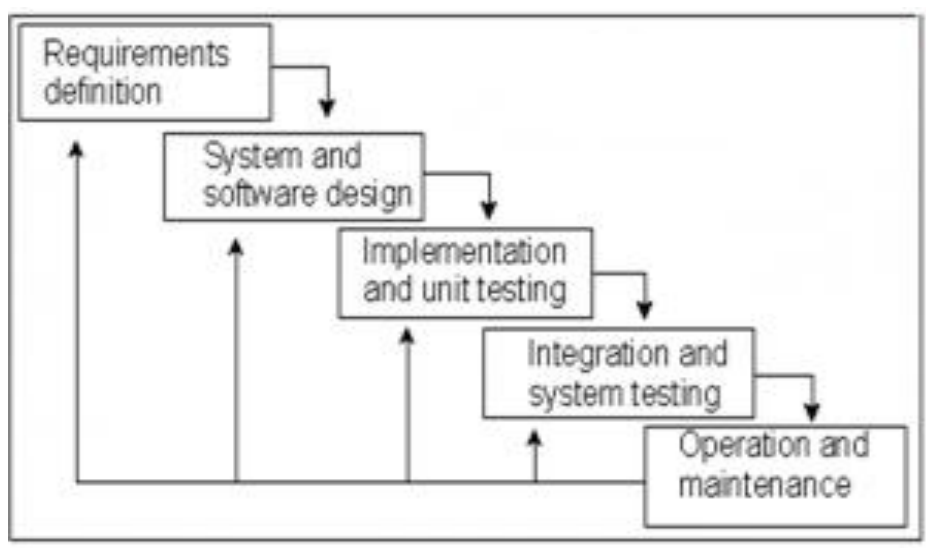

Figure 1. Waterfall Method [5] 


\section{RESULT}

\section{System Requirements Analysis}

To meet the system requirements, the author needs to conduct a survey of several respondents. Where the respondent's answer is a statement of what is needed in the design of the website-based queue retrieval application made by the author, which later is intended for the development of this application to be even better.

Table 1. System Requirements Analysis

\begin{tabular}{|c|l|c|}
\hline No. & \multicolumn{1}{|c|}{ System Requirements Analysis } & Information \\
\hline 1 & Has a display that is easy to understand & $\sqrt{ }$ \\
\hline 2 & Attractive design & $\sqrt{ }$ \\
\hline 3 & The application is not heavy & $\sqrt{ }$ \\
\hline 4 & Can be used on mobile devices & $\sqrt{ }$ \\
\hline 5 & Displays workshop information & $\sqrt{ }$ \\
\hline 6 & Can register and enter the customer's account & $\sqrt{ }$ \\
\hline 7 & After registering, the customer gets verified to the customer's email & $\sqrt{ }$ \\
\hline 8 & Queues can be taken anywhere and anytime & $\sqrt{ }$ \\
\hline 9 & Has a login menu & $\sqrt{ }$ \\
\hline 10 & Can take queues for the next few days & $\sqrt{ }$ \\
\hline 11 & Sending queue results to customer's email & $\sqrt{ }$ \\
\hline 12 & Print queue receipt & $\sqrt{ }$ \\
\hline 13 & Displays queue history & $\mathrm{X}$ \\
\hline 14 & Displays the status of the queue & $\sqrt{ }$ \\
\hline 15 & Has a feedback menu & \\
\hline 16 & Has a chat feature with the admin & \\
\hline 17 & Displays the queue report & \multicolumn{2}{|c|}{} \\
\hline
\end{tabular}

\section{Application Design}

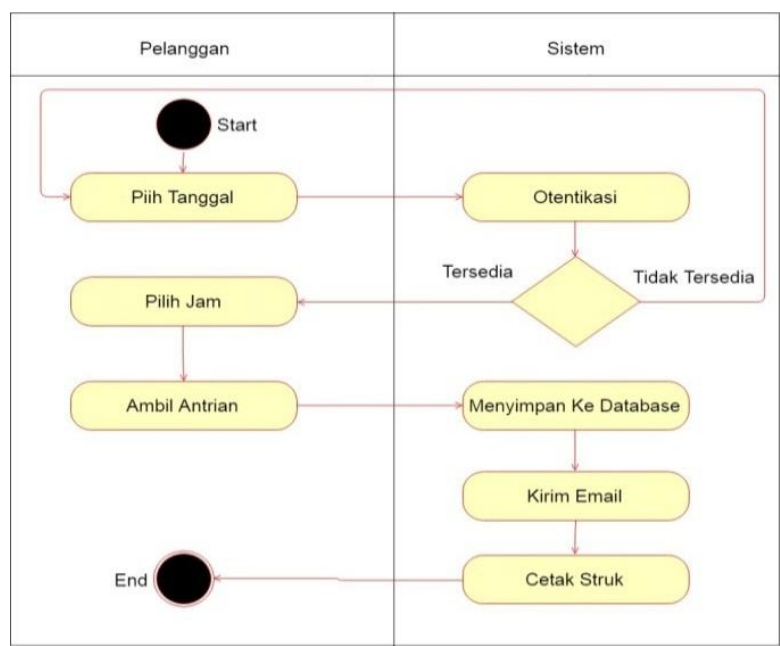

Figure 2: Activity Diagram Take A Queue

Based on Figure 2 Activity Diagram

Take a Queue in the Queue Application, there are:

a. 2 Swim Line, namely, Customer and System.

b. 1 Initial Node, as an object that starts. c. 7 Action State, which reflects the execution of an action namely, select date, authentication, select time, take queue, save to database, send email dan print receipt. 
d. 1 Decision Node, explain the results of e. 1 Final State, as an object that ends. the actions carried out.

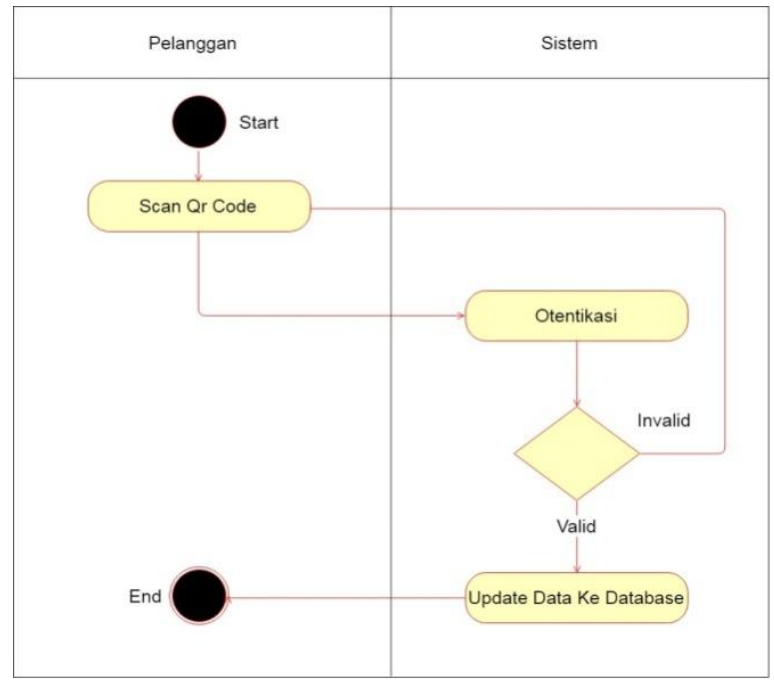

Figure3: Activity Diagram Queue Check

Based on Figure 3 Activity Diagram Queue Check in the Queue Application, there are:

a. 2 Swim Line, namely, Customer and Sistem.

b. 1 Initial Node, as an object that starts. c. 3 Action State which reflects the execution of an action namely, scan qr code, authentication dan update data to database.

d. 1 Decision Node, explain the results of the actions carried out.

e. 1 Final State, as an object that ends.

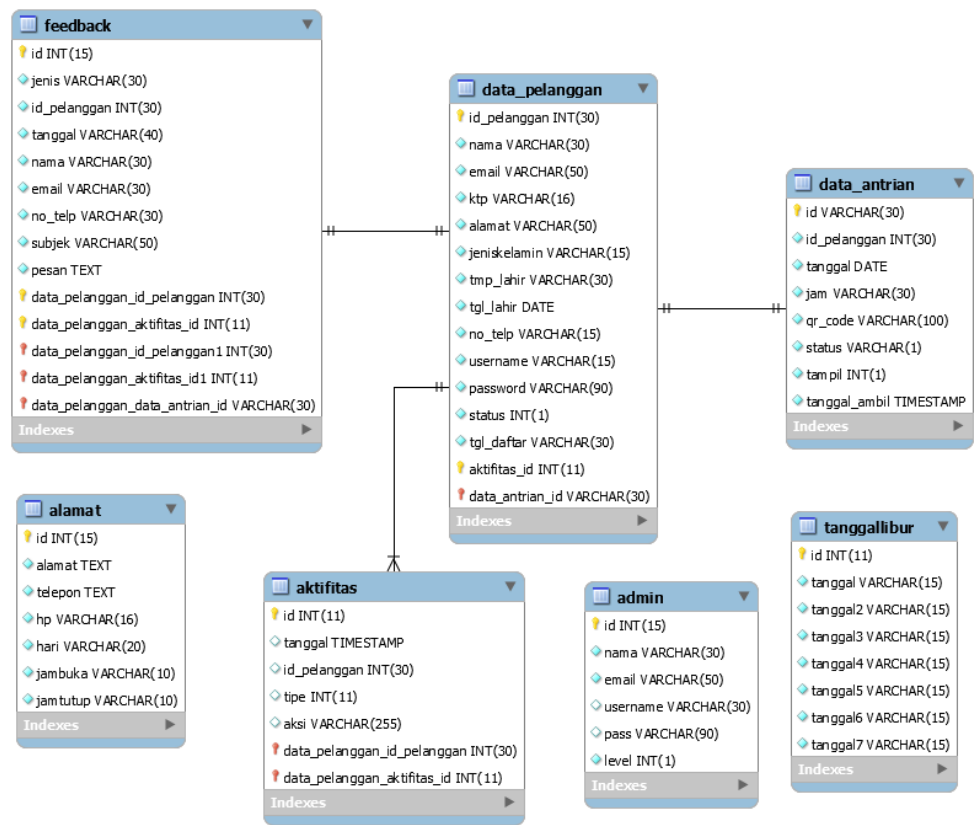

Figure 4: Design of Class Diagram Queue Application 


\section{Interface Display}

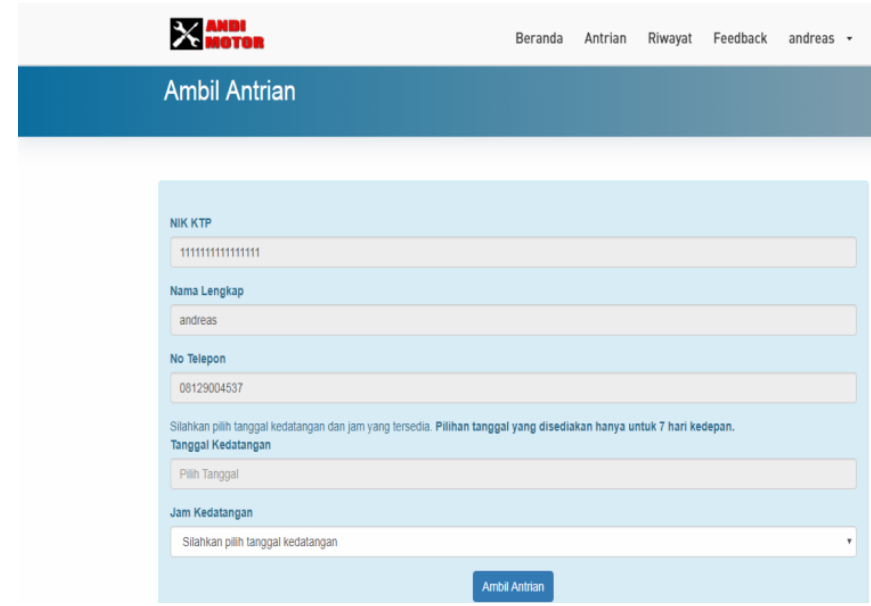

Figure 5: Display of Take a Queue Page

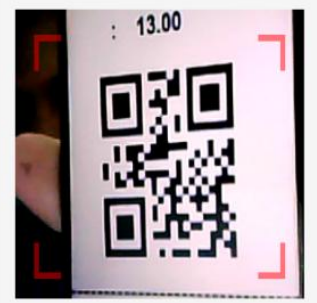

Figure 6: Display of Queue Check Page

\section{TESTING}

\section{Blackbox Testing}

For the application testing phase, the author uses the Blackbox Testing method with the State Transition Table technique, namely the test case is designed to check valid transitions, to ensure that the program or system that is created still has bugs (errors) or not. From each test case does not rule out there are still bugs (errors) from the system that has been tested. However, this test can at least minimize bugs (errors) contained in the system.

Table 2. Black Box Testing Take a Queue Page

\begin{tabular}{|c|c|c|c|c|c|}
\hline No. & $\begin{array}{c}\text { Testing } \\
\text { Scenario }\end{array}$ & Test Case & $\begin{array}{l}\text { Expected } \\
\text { Results }\end{array}$ & Test Result & Conclusion \\
\hline 1 & $\begin{array}{l}\text { Successfully } \\
\text { Take Queue }\end{array}$ & 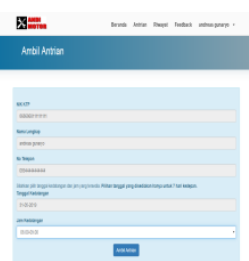 & $\begin{array}{l}\text { Displays a } \\
\text { Warning That } \\
\text { Take the Queue } \\
\text { successfully }\end{array}$ & 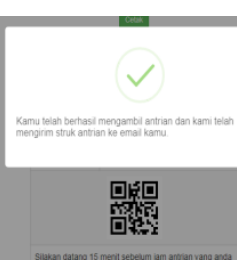 & Valid \\
\hline
\end{tabular}




\begin{tabular}{|c|c|c|c|c|c|}
\hline 2 & $\begin{array}{l}\text { Trying to } \\
\text { take the } \\
\text { queue a } \\
\text { second time } \\
\text { on the same } \\
\text { date. }\end{array}$ & 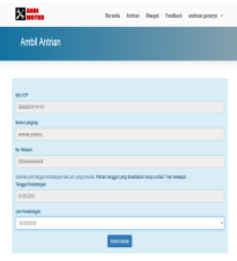 & 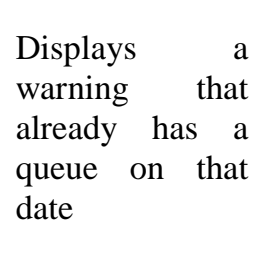 & 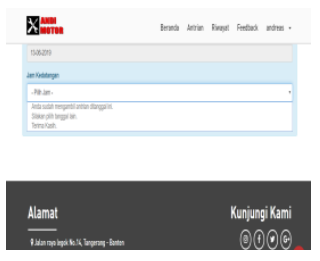 & Valid \\
\hline 3 & $\begin{array}{l}\text { Trying to get } \\
\text { a Queue } \\
\text { before } \\
\text { confirming } 2 \\
\text { queues that } \\
\text { were taken }\end{array}$ & 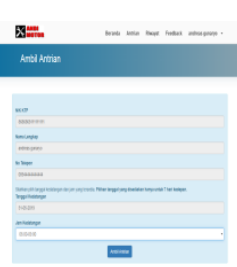 & $\begin{array}{l}\text { Display } \\
\text { warning that } \\
\text { already has } 2 \\
\text { queues not yet } \\
\text { confirmed }\end{array}$ & 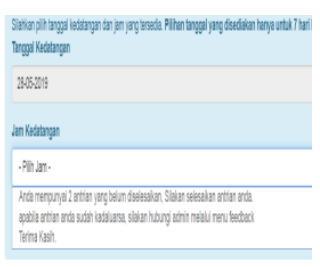 & Valid \\
\hline
\end{tabular}

This test aims to ensure that the queue customer has filled in the correct date and capture form in the queuing application can time of arrival data. work as expected. Queuing can be done if the

Table 3. Black Box Testing Check Queue Page

\begin{tabular}{|c|c|c|c|c|c|}
\hline No & $\begin{array}{c}\text { Testing } \\
\text { Scenario }\end{array}$ & Test Case & $\begin{array}{c}\text { Expected } \\
\text { Results }\end{array}$ & Test Resullt & Conclusion \\
\hline 1 & $\begin{array}{l}\text { Scan the } \\
\text { correct Qr } \\
\text { Code for that } \\
\text { day }\end{array}$ & 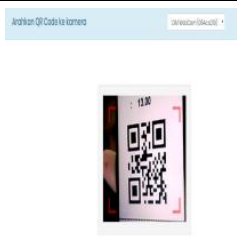 & $\begin{array}{l}\text { Displays a } \\
\text { warning that } \\
\text { successfully } \\
\begin{array}{l}\text { confirmed the } \\
\text { queue. }\end{array}\end{array}$ & 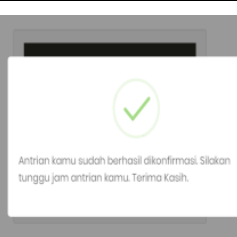 & Valid \\
\hline 2 & $\begin{array}{l}\text { Scan the } \\
\text { scanned Qr } \\
\text { Code for that } \\
\text { da }\end{array}$ & 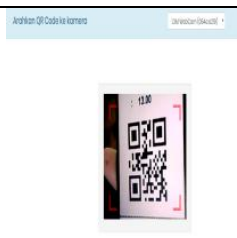 & $\begin{array}{l}\text { Displays a } \\
\text { warning that the } \\
\text { queue has been } \\
\text { confirmed that } \\
\text { day. }\end{array}$ & 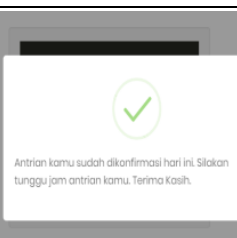 & Valid \\
\hline 3 & $\begin{array}{l}\text { Scan the } \\
\text { correct Qr } \\
\text { Code for the } \\
\text { day but it has } \\
\text { passed the } \\
\text { queue hour }\end{array}$ & 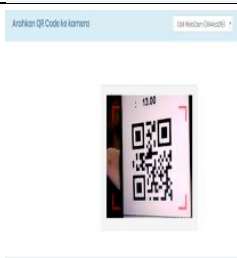 & $\begin{array}{l}\text { Displays a } \\
\text { warning that the } \\
\text { queue has } \\
\text { passed its } \\
\text { arrival time.. }\end{array}$ & 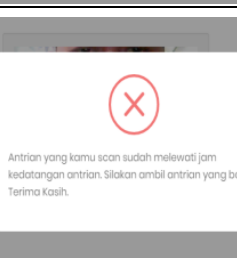 & Valid \\
\hline 4 & $\begin{array}{l}\text { Scan a Qr } \\
\text { Code that is } \\
\text { not for that } \\
\text { day }\end{array}$ & 㩆 & $\begin{array}{l}\text { Displays a } \\
\text { warning that the } \\
\text { queue is valid } \\
\text { but not for that } \\
\text { day. }\end{array}$ & 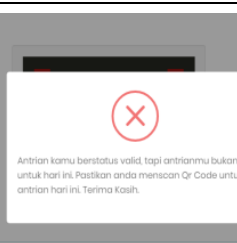 & Valid \\
\hline 5 & $\begin{array}{l}\text { Scan Qr } \\
\text { Code queues } \\
\text { that have } \\
\text { been } \\
\text { canceled }\end{array}$ & 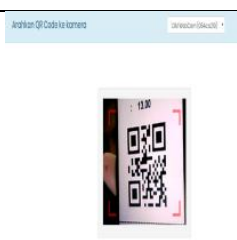 & $\begin{array}{l}\text { Displays a } \\
\text { warning that the } \\
\text { queue has been } \\
\text { canceled before. }\end{array}$ & 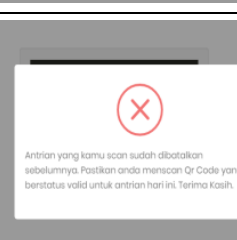 & Valid \\
\hline
\end{tabular}




\begin{tabular}{|l|l|l|l|l|l|}
\hline 6 & $\begin{array}{l}\text { Scan the Qr } \\
\text { Code used } \\
\text { the previous } \\
\text { day }\end{array}$ & $\begin{array}{l}\text { Displays a } \\
\text { warning that the } \\
\text { que has been } \\
\text { used the } \\
\text { previous day. }\end{array}$ & Valid \\
\hline 7 & $\begin{array}{l}\text { Scan an } \\
\text { expired Qr } \\
\text { Code }\end{array}$ & $\begin{array}{l}\text { Displays a } \\
\text { warning that the } \\
\text { queue has } \\
\text { expired. }\end{array}$ & Valid \\
\hline 8 & $\begin{array}{l}\text { Scan } \\
\text { unregistered } \\
\text { Qr Code }\end{array}$ & $\begin{array}{l}\text { Displays a } \\
\text { warning that the } \\
\text { queue is not } \\
\text { registered. }\end{array}$ & Valid \\
\hline
\end{tabular}

This test aims to ensure that the queue check page in the queue retrieval application canwork as expected. Queue checking can be done if the customer has scanned the correct qr code on the device used to scan.

\section{CONCLUSION}

After the design and testing of the application is done, the author can draw the following conclusions:

1. By using this website-based queuing application, it can facilitate customers in queuing, because customers can take and wait for queues anywhere and anytime without having to wait long at Andi Motor, so as to increase customer satisfaction in the queue taking process that is more enjoyable.

2. In this application, customers can display information about the queue time that customers take, so that customers feel easier and have the certainty of time to get service at Andi Motor.

3. In this application, customers can find out information about density or empty queues and can also find information related to Andi Motor so that it can facilitate customers who want to find information about Andi Motor.

4. In this application, there are several features to manage multiple reports that can facilitate Andi Motor in managing reports relating to customers, queues and complaints reports as well as input from customers, so that Andi Motor can continue to improve its services. 


\section{REFERENCES}

[1] Silaban. Desy C, “Analisis Kinerja Sistem Antrian M/M/1”, Jurnal Singuda Ensikom., Vol. 7, No. 3, Juni 2014, hh. 165-175.

[2] Nugroho. Adi, Rekayasa Perangkat Lunak Berorientasi Objek Dengan Metode USDP, Yogyakarta: Andi, 2010.

[3] Murad, Dina Fitria, Nia Kusniawati dan Agus Asyanto, "Aplikasi Intelligence Website Untuk Penunjang Laporan PAUD Pada Himpaudi Kota Tangerang”, Jurnal CCIT., Vol.7, No. 1, September 2013, hh. 44-58.

[4] Sutanto. Aris, Alat Perhitungan Jumlah Lembar Kertas Berbasis Internet Of Things Menggunakan Sensor Infrared Pada PT. Indah Kiat, Perguruan Tinggi Raharja: Tangerang, 2017.

[5] Sommerville. Ian, Software Engineering (Rekayasa Perangkat Lunak), Jakarta: Erlangga, 2011.

[6] Rizky. Soetam, Konsep Dasar Rekayasa Perangkat Lunak, Jakarta: Prestasi Pustaka, 2011.

\section{BIOGRAPHY}

Andreas Gunaryo Graduated from the Informatics Engineering Study Program (S1) concentration in Database, 2019.

Yusuf Kurnia Graduated in the Information Systems Study Program (S1) in Corporate System major at 2009, continue his magister at Computer Science (S2) in the Information Systems Technology. Now he is Currently active as a Lecturer in the Informatics Engineering Department, Buddhi Dharma University. 